\title{
LIVER FUNCTION IN RELATION TO POSSIBLE ABNORMALITIES OF STEROID METABOLISM IN RHEUMATOID ARTHRITIS
}

\author{
BY \\ L. M. H. ROY, F. W. WIGZELL, R. DEMERS, R. J. G. SINCLAIR, \\ J. J. R. DUTHIE, S. M. ATHERDEN, AND G. F. MARRIAN \\ From the Rheumatic Unit, Northern General Hospital, Edinburgh, and \\ the Department of Biochemistry, Edinburgh University
}

(RECEIVED FOR PUBLICATION FEBRUARY 2, 1955)

Sommerville, Marrian, Duthie, and Sinclair (1950) claimed to have shown conclusively that in patients suffering from rheumatoid arthritis an abnormally high proportion of progesterone administered by the intramuscular route was excreted in the urine as pregnanediol. Further results pointing to the same conclusion were subsequently obtained by Sommerville (1950).

These findings were thought to be of possible significance in connexion with the aetiology of rheumatoid arthritis, since the symptoms of that disease were known to be suppressed by cortisone, which is closely related chemically to progesterone and may be metabolized in the body in much the same way. As a preliminary to more extensive investigations which were being planned, it was thought desirable in the first instance to extend the observations on progesterone metabolism in a further series of normal and rheumatoid arthritic subjects.

Before the completion of this further series it was clear that, contrary to the findings of Sommerville and others (1950) and Sommerville (1950), there was no marked abnormality in the pregnanediol excretion in the majority of rheumatoid arthritic subjects, but, since some of the latter showed pregnanediol recoveries outside the range which had been regarded as "normal" by Sommerville and others (1950), it was felt that further investigations would be advisable.

There is some evidence from studies on human subjects and experimental animals that severe liver dysfunction may be associated with an abnormally high urinary excretion of pregnanediol after the administration of progesterone (Paschkis, Cantarrow, and Havens, 1951; Russell, 1952). Furthermore, it has been claimed by some authors (Rawls,
Weiss, and Collins, 1939; Hench, Bauer, Dawson, Hall, Holbrook, Key, and McEwan, 1941; Miller, 1935; Darby, 1953) that abnormalities in liver function occur not infrequently in rheumatoid arthritic subjects. Accordingly the possibility was considered that the apparent abnormalities in progesterone metabolism observed in some rheumatoid arthritic subjects might be confined to those with abnormalities in liver function. In view of this possibility, and of the conflicting results reported by various authors, it was decided to undertake a thorough investigation of liver function by a number of recognized tests in an unselected group of patients suffering from rheumatoid arthritis. This part of the study was specifically designed to investigate the possible association of impairment of liver function with abnormal progesterone metabolism. Only those cases showing significant abnormalities in liver function were to be submitted to tests of progesterone metabolism. At the same time it was decided to extend the observations on progesterone metabolism in a further group of normal and rheumatoid subjects.

The two parts of the investigation were to a large extent carried out independently. The results of the work on liver function are presented in Part I of this communication and those on progesterone metabolism in Part II.

\section{Liver Function in Rheumatoid Arthritis}

During the past 30 years many conflicting reports have appeared on liver function in relation to rheumatoid arthritis. The metabolism in the liver of protein and of carbohydrate has received most attention, but, although there is general agreement on the existence of abnormalities in protein metabolism, no such agreement can be found with respect 
of carbohydrates. The more general functions of liver-regulation of enzyme activity, detoxification, bile pigment and cholesterol metabolism, and secretory and excretory functions-have been much less widely investigated.

Hench and others (1941), in a general review of clinical and biochemical findings in rheumatoid arthritis, summarized previous work. They concluded that there is no evidence of any gross liver dysfunction, but stressed the difficulty of devising liver function tests delicate or specific enough for use in conditions where a minor dysfunction is suspected. The method of plasma protein fractionation used by early workers has been supplanted by the newer electrophoretic techniques. In this way, Routh and Paul (1950) were able to follow the plasma protein pattern throughout the different phases of the disease, and to show a direct relationship between the degree of abnormality and the severity of the disease. Other workers have confirmed these results. Despite this marked abnormality in protein metabolism, there is evidence of only slight quantitative and qualitative differences in the amino-acid composition of blood or urine (Borden, Wallraff, Brodie, Holbrook, Hill, Stephens, Kent, and Kemmerer, 1950). Creatine levels in both blood and urine are reported as normal by Dawson and Salt (1952).

The hippuric acid recovery test, in which administered benzoic acid is conjugated with glycine in the liver, has been used to study detoxification. Lemon, Chasen, and Looney (1952), using this test in a study of glycine metabolism ( 20 per cent. of the aminoacid residue in collagen consists of glycine), found normal recovery figures in all stages of rheumatoid arthritis, except in severe cases when wasting was present, and in these blood glycine levels were reduced. From these results they concluded that the liver is functioning normally in arthritis, low recoveries being due to extrahepatic demands on glycine reserves. Rawls and others (1939), on the other hand, reported a high percentage of abnormal hippuric acid recovery values in patients suffering from rheumatoid arthritis.

These authors also claimed that 60 per cent. of their patients gave a high recovery figure in the azorubin $S$ test, suggesting a dysfunction of the liver's secretory and excretory function. No abnormal results were found by either Robinson (1943) or Lemon and others (1952), using the bromsulphophthalein test. The methods used by Rawls and Lemon are open to criticism in that slight alteration in either bile or blood volume will markedly affect the results.

The liver would appear to be functioning nor- mally in rheumatoid arthritis as judged by the $\frac{\text { गु }}{\bar{\sigma}}$ activity of plasma alkaline phosphatase (Steinberg $\subseteq$ and Suter, 1939), and of cholinesterase (Grob, Lilienthal, Harvey, and Jones, 1947). There are, however, very few figures available, and little $\overrightarrow{\vec{F}}$ significance can be placed on isolated values as they $\stackrel{\vec{P}}{+}$ give no indication of the general trend of the enzyme activity of the individual.

Block, Buchanan, and Freyberg (1941) and Lemon $\frac{\bar{\sigma}}{\sqrt{6}}$ and others (1952) found no abnormality in either $\stackrel{\circ}{\complement}$ cholesterol or phospholipid metabolism in rheumatoid arthritis. During wasting and malnutrition, $\vec{\circ}$ Wells, Lowrey, and Ross (1951) found low plasma cholesterol levels, but normal levels are reported in $\vec{\omega}$ less severe stages of the disease.

Knowledge of the metabolism of bile pigment is $\frac{\text { a }}{2}$ scanty, the figures for plasma bilirubin being varied $\vec{A}$ and unreliable (Rawls and others, 1939). Pem- i berton and Foster (1920) were the first to report $\vec{D}$ evidence of abnormal carbohydrate metabolism inc rheumatoid arthritis. In a group of sixty patients, 옥 a high proportion showed decreased glucose toler- ance following the oral administration of $100 \mathrm{~g} . \subseteq$ glucose. They stated that there was a definite relationship between the degree of abnormality and $\vec{\varphi}$ the activity of the arthritis. Improvement in the disease was accompanied by a return to a mose normal response. Shackle and Copeman (1933) confirmed the finding of Pemberton and Foster, bitt Kersley (1937) reported that sugar tolerance waso normal in the majority of cases. Flynn and Irishő (1946) used Soskin's intravenous glucose tolerance 2 test to eliminate possible errors arising from faulty $\overrightarrow{0}$ absorption from the alimentary tract. They com-3 pared rates of clearance in 64 cases of rheumatoid $\mathcal{F}$ arthritis and sixty normal controls; in only $12 \cdot 5$ ? per cent. of the rheumatoid group had the blood@ sugar level returned to normal within 60 minutes as? compared with 71.7 per cent. of the controls. To 3 investigate the possibility that the delayed clearance. in rheumatoid arthritis might be due to diminution $\frac{3}{3}$ of peripheral glycogen depots in the presence of muscle atrophy, they applied the test to nineteen? cases of severe poliomyelitis. The curves in allo these patients showed a more rapid clearance than in healthy controls.

The results of fructose tolerance tests performed by Kimball (1932) and by Miller (1935) are contra- N dictory, but may be disregarded as both authors $\omega$ measured total blood sugar and so lost the advantages of this test. Although glucose tolerance tests gave normal results in all of eleven cases studied by Weber (1939), Wells and others (1951) found ${ }^{+}$ evidence of slight abnormality. Rawls and others (1939) reported an abnormality in the metabolism $\vec{D}$ 
of galactose in 14 per cent. of patients examined, but did not stress these results as they considered the test unsatisfactory.

\section{Methods and Materials}

The tests were chosen to cover as wide a range of liver function as possible, and, with few exceptions, the methods used were the standard procedures described in the literature:

The following tests were performed:

(1) Plasma bilirubin (Haslewood and King, 1937)

(2) Urinary urobilinogen (Wallace and Diamond,1925).

(3) Bromsulphophthalein retention test (Ingelfinger, Bradley, Mendeloff, and Kramer, 1948).

(4) Hippuric acid test (Quick, 1940).

(5) Serum alkaline phosphatase (Bessey, Lowry, and Brock, 1946).

(6) Serum cholinesterase (Michel, 1949).

(7) Plasma cholesterol (Kerr and Bauld, 1953).

(8) Zinc turbidity (Kunkel, 1947)

(9) Thymol turbidity (Shank and Hoagland, 1946).

(10) Plasma protein pattern (Tiselius' electrophoretic technique, Tiselius, 1938).

(11) Urinary amino acid composition (Dent, 1951).

(12) Fructose tolerance test (Stewart, Scarborough, and Davidson, 1947).

Initially the tests were performed, where possible, on a group of students, and the figures so obtained were found to fall within the normal range given by the authors of the methods. In all, 44 hospital patients were examined; 29 of these suffered from rheumatoid arthritis, the remaining fifteen being patients from a general medical ward. This latter control group was considered more suitable for comparison with the rheumatic group in respect to age, general mobility, and diet than healthy young students.

The 29 patients with rheumatoid arthritis represented a random sample of the admissions to the Rheumatic Unit, Northern General Hospital. All presented unequivocal signs of the disease and were admitted because of the need for hospital treatment. Patients in the control group had been admitted to hospital for a variety of conditions, but in the majority (thirteen of fifteen) the blood sedimentation rate was within the normal range at the time of the investigation. A note was made of the diagnosis and clinical history in each case. The distribution in the rheumatoid group with regard to sex, age, duration of disease, clinical assessment, haemoglobin level, and erythrocyte sedimentation rate is shown in Table I.

Basic information regarding the controls is also shown, but details of diagnosis and duration of disease are omitted as no significant correlations were apparent.

A low fat, high carbohydrate diet was given for $\mathbf{4}$ days before and throughout the three days of the test period. All drugs were withheld. Urine was collected for the first 24 hours. The various tests were performed during the next 2 days. Fasting blood was used for all determinations and the time of withdrawal controlled in order to avoid any diurnal variation.

One patient, with cardiovascular disease and an enlarged liver in addition to rheumatoid arthritis, gave
TABLE I

AGE, SEX, AND CLINICAL ASSESSMENT OF RHEUMATOID PATIENTS AND CONTROLS

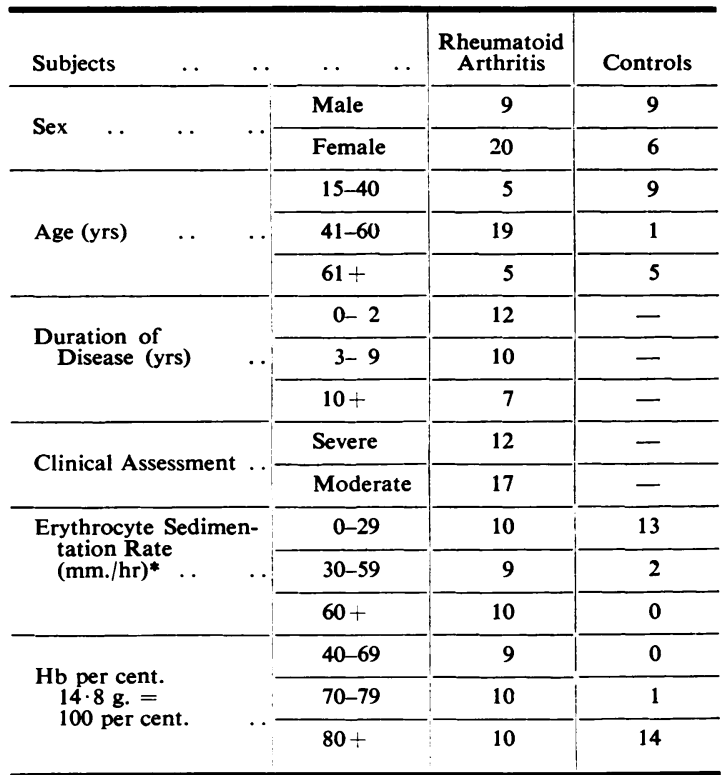

* E.S.R. was measured in Westergren tubes, using blood treated with Wintrobe's dry mixture of ammonium and potassium oxalate as anticoagulant.

abnormal results in nearly every test on two occasions, and these have been omitted from the general discussion.

\section{Results}

Plasma Bilirubin and Urobilinogen.-No evidence of abnormality in the metabolism of bile pigment was found in any of the cases examined. Values for bilirubin were all well below the level of $1 \cdot 2 \mathrm{mg}$. per cent. Urobilinogen was present in amounts too small to be detected in dilutions exceeding $1: 20$, with the exception of one case in which a positive result was obtained at a dilution of $1: 30$.

Hippuric Acid Recovery Test.-Using the conditions laid down by Quick (1940), 45-55 per cent. of benzoic acid fed to normal individuals can be recovered as hippuric acid in the urine. The results in 25 of 28 cases of rheumatoid arthritis fell within this range. In three patients recoveries were below 45 per cent. $(40,43$, and 28$)$; the last result might be explained by an incomplete urine sample, the volume being very low. Among the fifteen controls only one low recovery (40 per cent.) was recorded.

Serum Alkaline Phosphatase.-In only one rheumatoid patient did alkaline phosphatase activity exceed the normal range. It was subsequently shown that this patient also suffered from Paget's disease. 
In the control groups results all fell within the normal range.

Serum Cholinesterase.-Results in both controls and rheumatoid patients fell within the normal range of 0.6 to 1.2 units.

Plasma Cholesterol.-Using a chromatographic method, no abnormality was found in either the total cholesterol level or the ester-free ratio in any case studied.

Urinary Amino Acids.-Although the results of separating urinary amino acids by paper chromatography cannot be interpreted on a strictly quantitative basis, they give a reasonably good general picture. Compared with results in controls and normal individuals there was no evidence of a quantitative or qualitative difference in the pattern of amino acids excreted by patients suffering from rheumatoid arthritis. Glycine, glutamic or aspartic acid, serine, lysine, valine, and occasionally taurine were present.

Zinc and Thymol Turbidity Tests.-When the results of these tests were expressed as standard units (Table II) no values outside the normal range were recorded in the group of healthy students. In the control group of hospital patients abnormal values were found in a small number (Z.T., 1; T.T., 5). In the 28 rheumatoid patients there was a much higher proportion of abnormal results (Z.T., 8; T.T., 19).

TABLE II

DISTRIBUTION OF TURBIDITY FIGURES*

\begin{tabular}{|c|c|c|c|c|c|c|c|}
\hline \multirow{3}{*}{ Groups } & & \multicolumn{3}{|c|}{ Zinc Turbidity } & \multicolumn{3}{|c|}{ Thymol Turbidity } \\
\hline & & \multicolumn{2}{|c|}{$\begin{array}{l}\text { Normal } \\
\text { Range }\end{array}$} & \multirow{2}{*}{$16-24$} & \multicolumn{2}{|c|}{$\begin{array}{c}\text { Normal } \\
\text { Range }\end{array}$} & \multirow{2}{*}{$12-20$} \\
\hline & & $0-8$ & $8-16$ & & $0-4$ & $4-12$ & \\
\hline Students & $\cdots$ & 7 & 3 & 0 & 8 & 0 & 0 \\
\hline Rheumatoid Patients & $\cdots$ & 10 & 10 & 8 & 9 & 15 & 4 \\
\hline Controls . . & .. & 9 & 5 & 1 & 10 & 5 & 0 \\
\hline
\end{tabular}

Plasma Protein Pattern.-In the early stages of the investigation the plasma protein pattern was examined in twelve patients by the moving boundary Tiselius electrophoresis technique. A 2- to 3-fold increase in fibrinogen was found in every case. The $A / G$ ratio was reduced, and in those showing the most abnormal patterns there was a slight decrease in the $\alpha$-and $\beta$-globulin fractions.

In Fig. 1 (opposite), the electrophoretic pattern of the plasma proteins from a normal individual $(a)$ is contrasted with those from three rheumatoid patients; (b) represents the typical pattern in rheu- matoid arthritis; (c) reveals the presence of an exceptionally large amount of $\gamma$-globulin, and $(d)$ a very high fibrinogen content. These observations are in accordance with those reported by other workers.

Fructose Tolerance.-It is known that a significant $\overrightarrow{\vec{D}}$ proportion of glucose is metabolized outside the liver. In order to obtain more accurate information as to carbohydrate metabolism within the liver, the $\frac{\bar{\sigma}}{\bar{c}}$ fructose tolerance test was used in the present $\frac{\vec{\sigma}}{\vec{\alpha}}$ investigation. It is agreed that the liver is largely responsible for the metabolism of this sugar. The method of estimation is specific for fructose which is $\overrightarrow{0}$ not normally present in the peripheral blood. Results may therefore be considered more reliable $\vec{\omega}$ than those obtained when glucose is used. Stewart and others (1947) claim that, in normal subjects $\vec{a}$ after the ingestion of $50 \mathrm{~g}$. fructose, the level of $\vec{A}$ fructose in the blood never exceeds $20 \mathrm{mg}$. per cent. is and falls to below $8 \mathrm{mg}$. per cent. in 2 hours. The $\vec{\infty}$ distribution of results in the rheumatoid and control groups (hospital patients) are shown in Table III. $)$

TABle III

DISTRIBUTION OF FRUCTOSE TOLERANCE TEST FIGURES

\begin{tabular}{|c|c|c|c|c|c|c|}
\hline \multirow{3}{*}{ Groups } & \multicolumn{3}{|c|}{ Maximum } & \multicolumn{3}{|c|}{ 2-hr Value } \\
\hline & \multicolumn{2}{|c|}{$\begin{array}{l}\text { Normal } \\
\text { Range }\end{array}$} & \multirow[t]{2}{*}{$20-25$} & \multicolumn{2}{|c|}{$\begin{array}{c}\text { Normal } \\
\text { Range }\end{array}$} & \multirow{2}{*}{ 8-12 } \\
\hline & $10-15$ & $15-20$ & & $0-4$ & $4-5$ & \\
\hline Rheumatoid Patients & 6 & 13 & 7 & 0 & 13 & 13 \\
\hline Controls.. & 6 & 6 & 1 & 0 & 11 & 2 \\
\hline
\end{tabular}

Among 26 rheumatoid patients, the results were abnormal in sixteen ( 60 per cent.), seven ( 23 per? cent.) exceeded the maximum limit of $20 \mathrm{mg}$. per cent., and thirteen (50 per cent.) showed values 0 above $8 \mathrm{mg}$. per cent. at the end of 2 hours. Only $\frac{5}{3}$ one ( 8 per cent.) of the thirteen controls exceeded $20 \mathrm{mg}$. per cent., and two (16 per cent.) showed slight delay in clearing the sugar from the blood.

Bromsulphophthalein Test.-The percentage disappearance rate of the dye from the blood after intravenous injection of $150 \mathrm{mg}$. bromsulphophthalein/sq. m. body surface was measured in $27 \%$ patients. In this method results are independent N of blood volume, and, within reasonable limits, of the dose. Samples of blood $(0.2 \mathrm{ml}$.) were obtained by finger prick, $6,12,18,24$, and $30 \mathrm{~min}$. after injection. The cells were spun out after dilution to $\stackrel{\circ}{-}$ $1 \mathrm{ml}$. with 0.9 per cent. $\mathrm{NaCl}$. $0.8 \mathrm{ml}$. of the super- of natant was transferred to a second tube containing $0.2 \mathrm{ml} .0 .5 \mathrm{~N} \mathrm{NaOH}$, and the colour thus developed was compared with that of a sample of blood $\mathbb{D}$ 


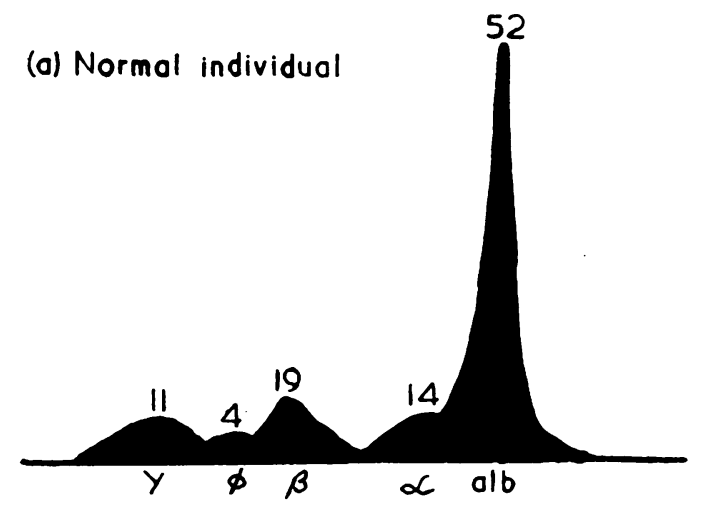

(c) Rheumatoid potient

(high $Y$-globulin)

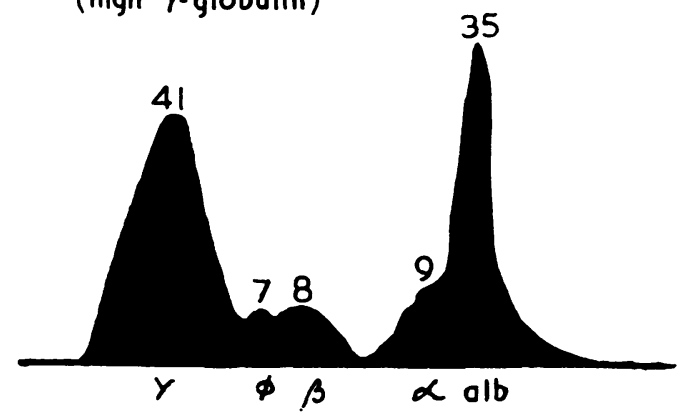

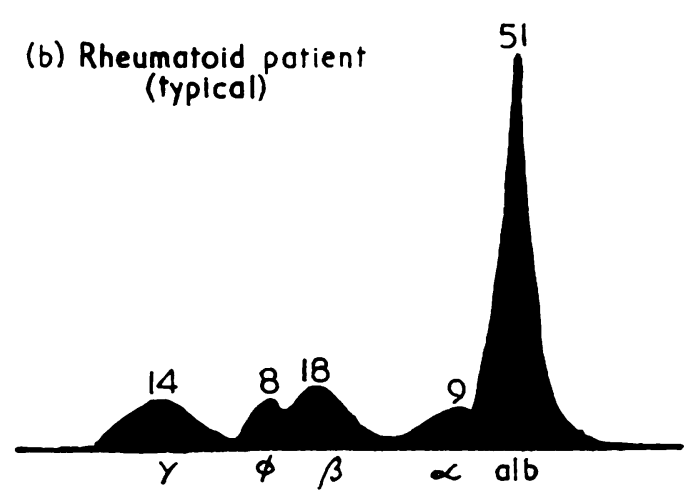

(d) Rheumotoid patient (high fibrinogen) obtained before injection of the dye. The results were plotted on a semi-logarithmic scale and the percentage disappearance rate per minute calculated. No difference was found between the values obtained in the rheumatoid group and from five healthy controls. Both sets of results were within the range of 12-14 per cent. The mean value given by Inglefinger and others (1948) for normal individuals is 13.8 per cent. Darby (1953), using the method of Mateer and others (1943) reported that in a group of fifty rheumatoid patients, 23 per cent. showed a significant degree of retention of bromsulphophthalein when the results of the tests were compared with those obtained in a control group of 45 hospital patients. In view of his findings, it was decided to re-examine, by the method of Mateer and others (1943), eleven of the original patients who were still available. The test was also applied in sixteen additional cases of rheumatoid arthritis and fifteen patients in an orthopaedic ward. The results are presented in Table IV (overleaf).

Using this method no dye should remain in the blood $45 \mathrm{~min}$. after injection. It will be seen that the mean value for dye retained at $45 \mathrm{~min}$. in the 27 rheumatoid patients $(0.5$ per cent.) does not significantly exceed that limit. The control group as a whole does not show a significant retention (1.7 per cent.), but two individuals retained $8 \cdot 5$ per cent. and 4.5 per cent. of the dye at $45 \mathrm{~min}$., though no history of liver disease was obtained in either of them. Taking all values below 1 per cent. as representing clearance, 10 .per cent. of the rheumatoid patients and 50 per cent. of the control group were over this value at 45 minutes. At $30 \mathrm{~min}$. the corresponding values in the two groups were 77 and 80 per cent. It is obvious that these results do not agree with those reported by Darby (1953). Although there is no significant retention of dye in either group, the control group tends to show a higher retention than the rheumatoid group. A histogram of the retention figures is given in Fig. 2 (overleaf).

\section{Discussion}

No comment is necessary except on the positive findings in the turbidity tests and protein fractions, the dye retention, and the fructose tolerance test. 
TABLE IV

PERCENTAGE RETENTION VALUES OF BROMSULPHOPHTHALEIN

\begin{tabular}{|c|c|c|c|c|c|}
\hline \multirow{3}{*}{ Case No. } & \multirow{2}{*}{\multicolumn{2}{|c|}{$\frac{\text { Controls }}{\text { Percentage Retention }}$}} & \multicolumn{3}{|c|}{ Rheumatoid Patients } \\
\hline & & & \multirow{2}{*}{ Case No. } & \multicolumn{2}{|c|}{ Percentage Retention } \\
\hline & $30 \mathrm{~min}$. & $45 \mathrm{~min}$. & & $30 \mathrm{~min}$. & 45 min. \\
\hline $\begin{array}{r}1 \\
2 \\
3 \\
4 \\
5 \\
6 \\
7 \\
8 \\
9 \\
10 \\
11 \\
12 \\
13 \\
14 \\
15\end{array}$ & $\begin{array}{r}5 \cdot 4 \\
2 \cdot 2 \\
2 \cdot 9 \\
3 \cdot 2 \\
0 \cdot 0 \\
0 \cdot 0 \\
2 \cdot 5 \\
5 \cdot 0 \\
2 \cdot 0 \\
11 \cdot 0 \\
1 \cdot 1 \\
5 \cdot 2 \\
0 \cdot 0 \\
9 \cdot 0\end{array}$ & $\begin{array}{l}2 \cdot 0 \\
2 \cdot 0 \\
1 \cdot 0 \\
0 \cdot 0 \\
1 \cdot 6 \\
0 \cdot 0 \\
0 \cdot 0 \\
0 \cdot 0 \\
2 \cdot 9 \\
0.9 \\
8 \cdot 5 \\
0 \cdot 0 \\
2 \cdot 2 \\
0.0 \\
4 \cdot 5\end{array}$ & $\begin{array}{r}1 \\
2 \\
3 \\
4 \\
5 \\
6 \\
7 \\
8 \\
9 \\
10 \\
11 \\
12 \\
13 \\
14 \\
15 \\
16 \\
17 \\
18 \\
19 \\
20 \\
21 \\
22 \\
23 \\
24 \\
25 \\
26 \\
27\end{array}$ & $\begin{array}{l}2 \cdot 7 \\
2 \cdot 4 \\
4 \cdot 9 \\
5 \cdot 1 \\
1 \cdot 4 \\
6 \cdot 1 \\
2 \cdot 0 \\
1 \cdot 8 \\
1 \cdot 6 \\
4 \cdot 3 \\
3 \cdot 7 \\
5 \cdot 1 \\
2 \cdot 0 \\
2 \cdot 3 \\
2 \cdot 5 \\
1 \cdot 0 \\
1 \cdot 0 \\
1 \cdot 5 \\
1 \cdot 4 \\
5 \cdot 1 \\
0 \cdot 5 \\
5 \cdot 5 \\
1 \cdot 3 \\
0 \cdot 9 \\
0 \cdot 7 \\
4 \cdot 6 \\
0 \cdot 0\end{array}$ & $\begin{array}{l}0.0 \\
0.9 \\
0.9 \\
0.6 \\
0.0 \\
1.0 \\
0.0 \\
0.0 \\
0.0 \\
2.0 \\
0.0 \\
1.0 \\
0.0 \\
0.5 \\
0.6 \\
0.0 \\
0.2 \\
0.2 \\
0.2 \\
1.3 \\
0.0 \\
2.7 \\
0.0 \\
0.0 \\
0.2 \\
0.5 \\
0.0\end{array}$ \\
\hline $\begin{array}{l}\text { Mean } \\
\quad \pm S . D .\end{array}$ & $3 \cdot 2 \pm 2 \cdot 7$ & $1 \cdot 7$ & & $2 \cdot 6 \pm 1 \cdot 7$ & 0.5 \\
\hline
\end{tabular}

The exact significance of the zinc and thymol turbidity tests in relationship to protein metabolism in the liver is not clear. Martin (1949) thought that abnormal thymol turbidities associated with liver damage depend on a disturbance of the intimate relationships of the serum albumin and globulins. Qualitative defects in albumin appear to be important in the production of the reaction in acute hepatitis, but abnormal globulins which contribute to the reaction have been demonstrated in the sera of patients with no other evidence of liver disease. The intensity of the turbidity also depends on the amount of lipid in the serum (Maclagan, 1944;
Kunkel and Hoagland, 1947). Reactions above the $\frac{\text { गु }}{\tau}$ normal range in the zinc turbidity test are associated $\stackrel{\Phi}{\perp}$ with alterations in the globulins. A much higher 3 incidence of positive reactions occurred with thymol than with zinc in the group of rheumatoid patients.

The number of positive reactions in the control $\overrightarrow{\vec{D}}$ group of hospital patients was very much less. $\overrightarrow{0}$ A study of the plasma protein pattern in rheumatoid $\frac{C}{0}$ patients revealed abnormalities of varying degree, $\overline{\bar{\omega}}$ but the $A / G$ ratio was reduced in the majority. $\mathbb{D}$ An increase in $\gamma$-globulin and a slight reduction in $\alpha$ - and $\beta$-globulins were found in those with the ${ }^{\infty}$ most abnormal patterns. Positive turbidity tests $\vec{O}$ would be expected in these circumstances, but there $\overrightarrow{-}$ is no direct evidence that these changes in the plasma protein pattern in rheumatoid arthritis can be related to hepatic dysfunction. Similar devia-? tions from the normal pattern occur in a wide $\vec{A}$ variety of diseases in which other evidence of liver? damage is absent. No satisfactory explanation for $\vec{\omega}$ the marked increase in fibrinogen commonly found 0 in the active phase of rheumatoid arthritis has ever been offered, but this abnormality is not a feature $\vec{c}$ in cases with other evidence of liver damage. There is no satisfactory proof of a hyperimmune reaction ${ }^{\infty}$ in rheumatoid disease, but this possibility must be $\vec{\theta}$ considered in seeking an explanation for alteratioss in the globulin fractions.

Investigation of carbohydrate metabolism by fructose tolerance test revealed a significant differ ence between rheumatoid patients and controls, but the delay in clearing the sugar from the blood in the $\frac{Q}{2}$ former was not very marked. This evidence of $\underset{\vec{P}}{\overrightarrow{2}}$ slight impairment of carbohydrate metabolism in the $\frac{3}{3}$ liver is in agreement with results reported by a number of other workers.

Using the method of Ingelfinger and others (1948) for the bromsulphophthalein test, the percentage disappearance rate in all rheumatoid patients fello within the normal range. No significant retention of
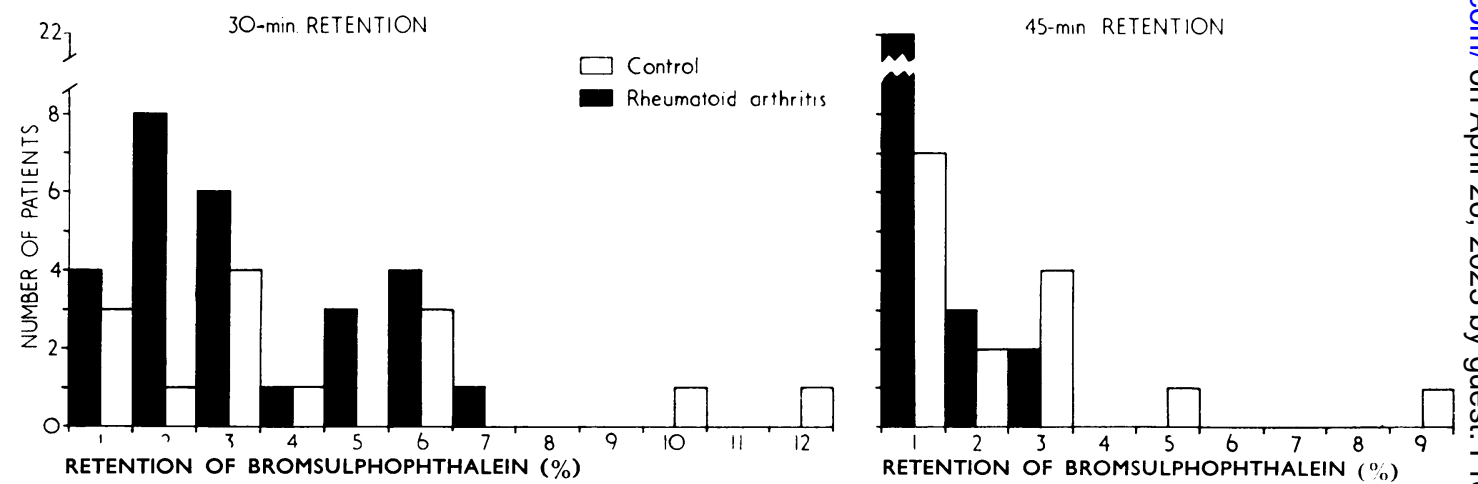

Fig. 2.-Results of bromsulphophthalein retention tests. 
dye was demonstrated in rheumatoids or controls when the method of Mateer and others (1943) was used. The results reported by Darby (1953) were not confirmed.

These results indicate that there is minimal evidence of liver damage in patients suffering from rheumatoid arthritis, but it is possible that the tests here reported are not sufficiently sensitive to reveal functional abnormalities which may be of significance in the pathogenesis of this disease.

II. Urinary Excretion of Pregnanediol after Administration OF Progesterone IN Normal INDIVIDUALS AND PATIENTS WITH RheumatoID ARTHRITIS

Methods.-Experimental subjects were injected intramuscularly with $50 \mathrm{mg}$. progesterone dissolved in $50 \mathrm{ml}$. olive oil, and 24-hour urine specimens were collected from each subject on the day before the injection and on the following 4 to 5 days. Pregnanediol determinations in duplicate were carried out on each specimen by the method of Sommerville, Gough, and Marrian (1948), and the total pregnanediol excretion calculated after correction for the "urine blank". Experiments were carried out on seventeen rheumatoid arthritic men, nine rheumatoid arthritic women, eight normal men and one normal woman.

Results. - These are shown in Fig. 3A, the results obtained by Sommerville and others (1950) and Sommerville (1950) being recorded alongside for the sake of comparison (Fig. 3B).

Discussion.-Although in the present work experiments were carried out on nine normal subjects only, it is clear that the normal range of pregnanediol recovery is considerably wider than was suggested by Sommerville and others (1950) and Sommerville (1950). In fact, four of these nine subjects showed pregnanediol recoveries which previously would have been regarded as abnormally high.

Of the 26 rheumatoid arthritic cases studied, 21 showed pregnanediol recoveries within the normal range as determined in the present work, and no fewer than eleven showed recoveries falling within the normal range of Sommerville and others (1950) and Sommerville (1950).

It is clear that, contrary to the claim of Sommerville and others (1950), there is no consistent difference between normal and rheumatoid arthritic subjects in the urinary excretion of pregnanediol after the intramuscular administration of progesterone. No satisfactory explanation of the discrepancy between the present findings and those

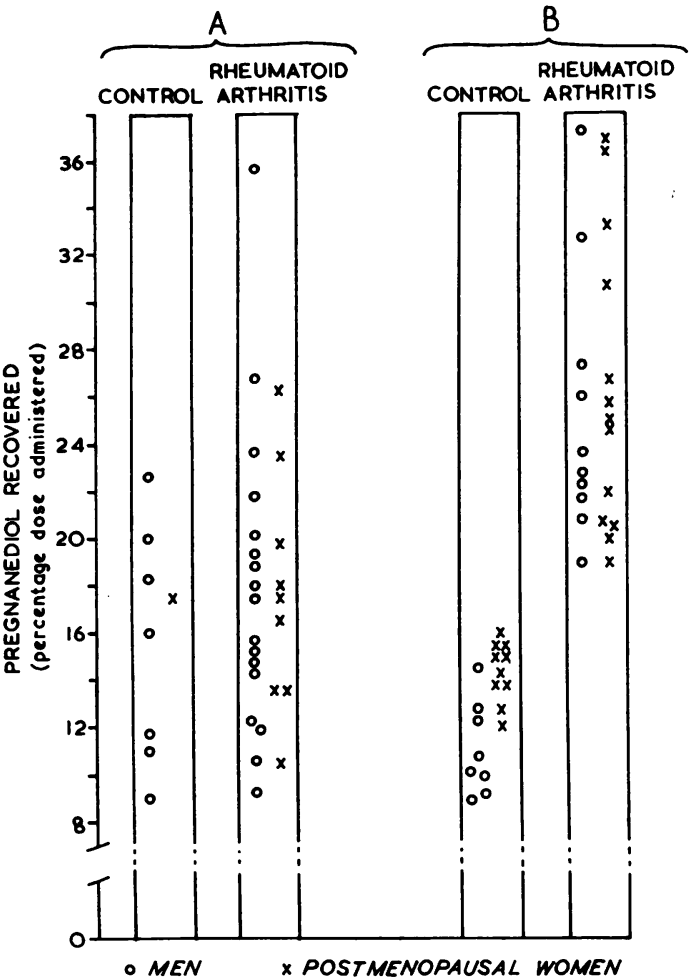

Fig. 3.-Urinary excretion of pregnanediol by normal and rheumatoid arthritic subjects after intramuscular progesterone.

(A) Present investigation, using a single dose of $50 \mathrm{mg}$. progesterone.

(B) Sommerville and others (1950) and Sommerville (1950), using two doses of $60 \mathrm{mg}$. progesterone on successive days, or a single dose of $60 \mathrm{mg}$. progesterone.

of Sommerville and others (1950) and Sommerville (1950) can be put forward.

Since it has now become apparent that the metabolism of administered progesterone as judged by urinary pregnanediol excretion is not significantly abnormal, and since no satisfactory evidence of impairment of liver function had been obtained in the majority of patients investigated, the concept that there might be some association between the abnormal metabolism of progesterone and impaired liver function in rheumatoid arthritis has had to be abandoned.

\section{Summary}

(1) The results of a number of routine tests of liver function in patients with rheumatoid arthritis have been compared with those in other patients.

(2) There was no evidence of abnormality in the metabolism of bile pigment, excretion, detoxification, or enzyme activity in the liver in either group.

(3) In rheumatoid patients the plasma protein pattern was abnormal in a number of respects. 
There was a marked increase in fibrinogen, a reduction of the $A / G$ ratio, a decrease in the $\alpha-$ and $\beta$ globulins, and an increase in the $\gamma$-globulin. The zinc and thymol turbidity tests were positive in the majority of cases. There was no significant change in the pattern of amino acids in the urine. It is not considered that these signs of disturbance in protein metabolism necessarily arise as a result of altered liver function.

(4) Mild impairment of carbohydrate metabolism in the liver is suggested by delay in the clearance of fructose from the blood.

(5) Earlier reports of abnormal metabolism of progesterone have not been confirmed.

The Rheumatic Unit and the Department of Biochemistry were in receipt of grants from the Medical Research Council, and the Rheumatic Unit was in receipt of a grant from the Nuffield Foundation. One of us (R.D.) held a Fellowship from the Canadian Arthritis and Rheumatism Foundation. We are greatly indebted to Dr. H. Cruft, Department of Biochemistry, Edinburgh University, for performing the electrophoretic examinations of the plasma proteins, and to Dr. W. S. Bauld for his helpful advice on the selection of biochemical methods.

\section{REFERENCES}

Bessey, O. A., Lowry, O. H., and Brock, M. J. (1946). J. biol. Chem., $164,321$.

Block, W. D., Buchanan, O. H., and Freyberg, R. H. (1941). Arch. intern. Med., 68, 18.

Borden, A. L., Wallraff, E. B., Brodie, E. C., Holbrook, W. P., Hill, D. F., Stephens, C. A. L., Kent, L. J., and Kemmerer, A. R. (1950). Proc. Soc. exp. Biol. (N.Y.), 75, 28.

Darby, P. W. (1953). J. clin. Path., 6, 331 .

Dawson, J. E., and Salt, H. B. (1952). Annals of the Rheumatic Diseases, 11, 23.

Dent, C. E. (1951). "Recent Advances in Clinical Pathology", ed. S. C. Dyke, 2nd ed., p. 238. Churchill, London.

Flynn, J. E., and Irish, O. J. (1946). Science, 104, 344

Grob, D., Lilienthal, J. L., Harvey, A. M., and Jones, B. F. (1947). Bull. Johns Hopk. Hosp., 81217.

Haslewood, G. A. D., and King, E. J. (1937). Biochem. J., 31, 920.

Hench, P. S., Bauer, W., Dawson, M. H., Hall, F., Holbrook, W. P., Key, J. A., and McEwen, C. (1941). Ann. intern. Med., 14,1383

Ingelfinger, F. J., Bradley, S. E., Mendeloff, A. I., and Kramer, P. (1948). Gastroenterology, 11, 646.

Kerr, L. M. H., and Bauld, W. S. (1953). Biochem. J., 55, 872.

Kersley, G. D. (1937). Proc. roy. Soc. Med., 30, 611.

Kimball, S. (1932). Guy's Hosp. Rep., 82, 157.

Kunkel, H. G. (1947). Proc. Soc. exp. Biol. (N.Y.), 66, 217.

, and Hoagland, C. L. (1947). J. clin. Invest., 26, 1060.

Lemon, H. M., Chasen, W. H., and Looney, J. M. (1952). Ibid., 31, 993 .

Maclagan, N. F. (1944). Brit. J. exp. Path., 25, 15.

Martin, N. H. (1949). J. clin. Path., 2, 275.

Mateer, J. G., Baltz, J. I., Marion, D. F., and MacMillan, J. M. (1943). J. Amer. med. Ass., 121, 723 .

Michel, H. O. (1949). J. Lab. Clin. Med., 34, 1564

Miller, S. (1935). Rep. chron. rheum. Dis., 1, 53.

Paschkis, K. E., Cantarow, A., and Havens, W. P., Jr. (1951). Fed. Proc., 10, 101.

Pemberton, R., and Foster, G. L. (1920). Arch. intern. Med., 25, 243.

Quick, A. J. (1940). Amer. J. clin. Path., 10, 222.

Rawls, W. B., Weiss, S., and Collins, V. L. (1939). Ann. intern. Med., 12, 1455.

Robinson, G. L. (1943). Annals of the Rheumatic Diseases, 3, 207.

Routh, J. I., and Paul, W. D. (1950). Arch. phys. Med., 31, 511.

Russell, M.'E. (1952). "Some Aspects of Progesterone Metabolism in the Rabbit," Ph.D. Thesis, University of Edinburgh

Shackle, J. W., and Copeman, W. S. C. (1933). Brit. med. J., 1, 268.

Shank, R. E., and Hoagland, C. L. (1946). J. biol. Chem., 162, 133.

Sommerville, I. F. (1950). "Steroid Metabolism in Normal and Rheumatoid Arthritic Human Subjects." M.D. Thesis, University of Edinburgh.
Sommerville, I. F., Gough, N., and Marrian, G. F. (1948). J. J Endocrinol., 5, 247.

-, Marrian, G. F., Duthie, J. J. R., and Sinclair, R. J. G. (1950). Lancet, 1, 116.

Steinberg, C. L., and Suter, L. C. (1939). Arch. intern. Med., 64, 483.

Stewart, C. P., Scarborough, H., and Davidson, J. N. (1947). Edinb. med.J., 44, 105.

Tiselius, A. (1938). Kolloidzschr., 85, 129.

Wallace, G. B., and Diamond, J. S. (1925). Arch. intern. Med.,

W5, 698. 1939$). \quad$ Med. Bull. Vet. Admin., 15, 243.

Wells, B. B., Lowrey, R. D., and Ross, S. W. (1951). Amer. J. clin. Path., 21, 423.

La fonction hépatique par rapport à des anomalies probables du métabolisme des stéroides dans l'arthrite rhumatismale

\section{RÉSUMÉ}

(1) On a comparé les résultats d'un certain nombre de tests systématiques de la fonction hépatique chez des $\vec{\omega}$ malades atteints d'arthrite rhumatismale avec ceux obtenus chez d'autres malades.

(2) On n'a pas trouvé d'anomalies concernant le métabolisme du pigment biliaire, l'excrétion, l'activité $\vec{A}$ antitoxique ou enzymatique dans le foie de deux groupes. i

(3) Chez les rhumatisants on a trouvé des anomalies $\overrightarrow{0}$ des protéines plasmatiques revêtissant plusieurs aspects: le fibrinogène était bien augmenté, le rapport albumine/ o globuline diminué, les fractions alpha et beta de la globuline diminuées et la fraction gamma augmentée. Dans la plupart des cas les tests de turbidité du zinc $\subseteq$ et du thymol étaient positifs. On n'a pas observé de changement appréciable dans le tableau des acides aminés dans l'urine. On ne croit pas que ces signes de $\vec{\theta}$ dérangement du métabolisme des protéines dérivent of nécessairement de l'altération de la fonction hépatique.

(4) Le temps prolongé de l'élimination sanguine de fructose suggère l'existence $\mathrm{d}$ un dérangement bénin métabolisme carbohydré.

(5) On n'a pas confirmé les rapports antérieurs selon lesquels le métabolisme de la progestérone serait altéré.

\section{La función hepatica en relación a las anomalías probables del metabolismo de los esteroides en la artritis reumatoide SUMARIO}

(1) Se compararon los resultados de un número de determinaciones sistemáticas de la función hepática en enfermos con artritis reumatoide con los obtenidos en otros enfermos.

(2) No se encontraron anomalías del metabolismo del pigmento biliar, excreción, actividad antitóxica o enzimática en el hígado de ambos grupos.

(3) En los reumáticos varios aspectos del cuadro de las proteinas plasmáticas viéronse alterados: el $\mathrm{O}$ fibrinogeno fué apreciablemente aumentado, el cociente albumina/globulina disminuído, las fracciones alfa y beta de la globulina disminuídas y la fracción gama aumentada. En la mayoría de los casos las reacciónes $N$ de turbiedad del zinc y del timol fueron positivas. No se vío cambio apreciable en el cuadro de los amino-ácidos en la orina. No se cree que estas manifestaciones de desarreglo del metabolismo de las proteinas sean necesariamente el resultado de la alteración de la función hepática.

(4) La prolongación de la eliminación sanguínea de la fructosa sugiere la existencia de un desarreglo benigno del metabolismo carbohídrico.

(5) No se confirmaron los relatos anteriores según lo cuales el metabolismo de la progesterona sería alterado. 